\title{
Bacterial contamination of retailed syrups traded in Wukari, North East, Nigeria
}

Edobor Peter Kenneth Imarenezor*, Onolunosen Abel Abhadionmhen, Paula Paul Shinggu, Joyce Briska, Ochanya Susan George and Sunday Danya

Tropical Diseases Unit, Department of Microbiology, Faculty of Pure and Applied Sciences, Federal University Wukari, Taraba State, Nigeria.

International Journal of Biological and Pharmaceutical Sciences Archive, 2021, 02(01), 117-125

Publication history: Received on 12 July 2021; revised on 19 August 2021; accepted on 21 August 2021

Article DOI: https://doi.org/10.53771/ijbpsa.2021.2.1.0073

\begin{abstract}
There is an increasing concern that syrups may contain pathogenic or non-pathogenic microbes that can pose as public health risk to patients. This research was to investigate the bacterial contamination of retailed syrups sold in Wukari. Eighteen (18) different brands of syrups were collected from different medicine stores in Wukari, North East Nigeria. These various brands of syrups were taken to the Microbiology Laboratory, Federal University Wukari for analysis using standard bacteriological techniques. The results show that syrups samples with contaminants included the M \& B paracetamol, Emzor paracetamol, M \& B flagyl (Loxagyl), Emzor Chloroquin, M \& B Antimalarial preparation (Artelumex), Emzor cough syrup (Emzolyn), Emzor digestion syrup (Emtrisil), Jawa digestion syrup (Jawasil), Emzor multivitamin (Emvite), Tuyil pharmacy multivitamin (Vami-vite), Emzor blood tonic, and Jawa blood tonic while those that contained no contaminants included the Emzor flagyl(Emgyl), M \& B chloroquin(Vinaquin), Emzor antimalarial preparation (Lokmal), Jawa cough syrup(D-Koff), Emzor vitamin c and Tuyil pharmacy vitamin C. The researched revealed that twelve (12) of the syrups were contaminated with bacteria isolates of Bacillus spp 9 (45\%), Lactobacillus spp 5 (25\%), Proteus spp 2 (10\%), Staphylococcus aureus 2 (10\%), Pseudomonas spp 1 (5\%) and Klebsiella spp 1 (5\%). The presence of the isolates could possibly be as a result of the production process and improper handling and protection of the containers containing the products. It is therefore recommended that monitoring agencies should ensure that these syrups do not present health hazards to the public during production and retail of products.
\end{abstract}

Keywords: Contamination; Bacterial; Brand; Retail drugs; Wukari; Syrups

\section{Introduction}

Syrup is a concentrated sugar solution such as sucrose in water or other aqueous liquid, sometimes with a medicinal agent added; usually used as a flavoured vehicle for drugs. It is commonly expanded to include any liquid dosage form (oral suspension for example) in a sweet and viscid vehicle [1]. Syrups are staples in the pharmaceutical industry, particularly for children and other individuals who cannot swallow tablets because they are liquid. However, these products face unique challenges in their production process. The mixing technology chosen for a given product will have a significant impact on its effectiveness and overall quality as the occurrence of microbial contamination has been well documented; contaminants range from true pathogens such as Clostridium tetani to opportunistic pathogens such as Pseudomonas aeuruginosa [2]. Several reports have also been published describing clinical hazards that are attributed to microbiologically contaminated syrups.[3]. Since the manufacturing of syrups involves a series of unit operation such as milling, granulation, coating, tablet pressing and others, they may be exposed accidentally to microorganisms and this mishandling may result in a series of health hazard following ingestion of the highly contaminated drugs by patients whose immunity is already compromised by illness [4]. Microbial infections are not only the result of the physical

\footnotetext{
${ }^{*}$ Corresponding author: Edobor Peter Kenneth

Tropical Diseases Unit, Department of Microbiology, Faculty of Pure and Applied Sciences, Federal University Wukari, Taraba State, Nigeria.
}

Copyright $(2021$ Author(s) retain the copyright of this article. This article is published under the terms of the Creative Commons Attribution Liscense 4.0. 
presence of microorganisms, but also their metabolites/toxins that become harmful even if they are found in minute quantities [5]. Some of these toxin-related illnesses include acute gastroenteritis, abdominal discomfort, and diarrhoea. Symptoms vary from mild gastric distress to death, depending on individual susceptibility to the toxin, amount of ingested toxin, and general health of the victim [5]. The more serious problem arising from microbial contamination of drugs is the absence of obvious signs of spoilage, therefore there is a need to know the microbial content of all drug and medicines whether they be sterile or non-sterile [6]. A number of factors including availability of nutrients, oxygen and presence of microorganisms are responsible for spoilage of any pharmaceutical product. The outcome of the consumption of contaminated drugs will depend on the type and degree of the microbial contamination, the extent of deterioration, and the route of entry and also on the patient's immune status [7]. This presence of microbial flora in the pharmaceutical product whether pathogenic or non-pathogenic forces the consumer to lose faith in the manufacturing company; which may also cause the considerable financial defeats of the manufacturer due to microbe mediated changes in the stability of the pharmaceuticals [8]. Metabolic versatility of bacteria helps them to utilize and transform a variety of ingredients of the formulation of pharmaceutical products [9]. Therefore, it is essential to determine the microbial load of all pharmaceutical products, whether sterile or non-sterile to ensure good quality of the product [10]. However, very few studies have been carried out on the microbiological quality of the pharmaceutical products like oral suspension in Bangladesh [11]. There are various medical syrups, like the cough syrups, which are medications used for those with cough related conditions although it is not known whether or not over the counter cough medications reduce coughing [12]. According to [13], other groups of syrups include the prophylactic syrups, iron syrups, calcium syrups, and syrups for digestion, vitamin syrups, anti-allergy syrups, blood tonic, and antimalarial syrups. Some of the most popular syrups are the Paracetamol, Amoxicillin, Multivitamins, Erythromycin, Arthemeter, Antacid and a host of others. Medicinal syrups are of two types: the one made from extractive drugs: Here, the fluid extract of the respective medicines is mixed with the syrup and those made from chemicals: This can be either by simple solution or by chemical reaction and solution. Here the taste of the medicinal agents is greatly modified. Microbial contamination refers to the non-intentional or accidental introduction of microbes such as bacteria, fungi, virus, prions, protozoa or their toxins and by products. Microbial contaminations are of two types: the direct contamination in which contamination is by microbial components and poorly maintained heating, ventilation and air conditioning (HVAC) systems and the cross contamination which involves passing microorganism or other harmful substances indirectly from one sample to another through improper and unsterilized equipment [14]. It has also been reported that both Gram positive and Gram negative bacteria are able to survive for months on dry inanimate surfaces, with longer persistence under humid and lower temperature conditions [15]. Pharmaceuticals are used in a variety of ways in the prevention, treatment, and diagnosis of diseases. In recent years, manufacturers of pharmaceuticals have improved on the quality of non-sterile pharmaceuticals such that today such products contain only minimal bio burden [16]. Pharmaceutical product crosscontamination refers to the process by which foreign chemical, microbial, or physical substances are unintentionally transferred from one substance or object to medicines with harmful effects that might affect the purity and quality of the pharmaceutical products leading to health impacts on human and animal users [17]. Products in which contamination is likely to be most significant are those administered by injection [18] or applied to open wounds and those given in large doses and/or over a long time. Cross-contamination in pharmaceuticals has been addressed elsewhere as a serious problem with evidence of product recall [19]. The main sources of cross-contamination in drug manufacturing are human beings, air, equipment, water, and raw materials. Human beings carry normal flora such as Staphylococcus aureus and may serve as the main source of microbial cross contamination during manufacturing of pharmaceuticals [20]. This contamination has clinical implications because it may be a way of introducing bacterial toxins and pathogens into medicines. In sterile preparations for injections this can cause life threatening anaphylactic reactions [21]. The use of cross-contaminated medicines and medical equipment has been reported to cause Staphylococcus aureus sepsis in patients [22]. Microbial cross-contamination of pharmaceuticals is associated with appearance of bacterial strains resistant to antimicrobials [23]. Antimicrobial resistance has some economic consequences because it requires a patient to buy expensive drugs which the organisms are sensitive to, increases duration of hospital stay and may require further expensive investigations [24]. The current Good Manufacturing Practices require that in a pharmaceutical industry, all workers wear special clothes before entering the production area. Regular alcohol hand washing is required and regular hand swabs are taken for culture by the quality control department. It is known that a certain proportion of the population is sensitive to penicillin [25]. Therefore such products require special handling. However, penicillin products may cross contaminate other medicines especially during campaign production. Drug sensitivity does not only affect the quality of patients' life but also leads to delayed treatment and increases treatment costs. The current Good Manufacturing Practice requires that production of penicillin and other preparations liable to be contaminated such as live vaccines, live bacterial preparations and other biological materials like insulin be carried out in dedicated and self-contained areas [26]. In the hospital setup the main sources of drug contamination depend on human practices such as preparation of drugs for intravenous administration [27], poor dispensing practices, and poor adherence to medicine storage conditions [28]. Poor storage of medicines in homes can also be a source of contamination. It is presumed that improved packaging of products in blisters may eliminate this problem. Cross-contamination of medicines contributes to most of the nosocomial infections occurring in 
hospitals [29]. Cross-contaminated medicines weaken the relationship between patients and healthcare givers. This occurs mostly in the event of drug resistance and treatment failure, but also infections due to contaminated medicines make patients lose trust in their health care givers [30]. In campaign production, more than one drug is manufactured in the same production line. This is the source of cross-contamination since residuals of former drug may be passed to the latter drug. The current Good Manufacturing Practices suggest that there should be separation in time followed by appropriate cleaning in accordance with a validated cleaning procedure [31]. Air carries a lot of materials, both organic and inorganic which may be potential contaminants in pharmaceuticals manufacturing. To avoid air contamination during manufacturing it is a requirement that pharmaceutical industries provide appropriately designed airlocks, pressure differentials, and air supply extraction system. Pipes used for conveying distilled or de-ionized water and, where appropriate, other water pipes should be sanitized and stored according to written procedures that detail the action limits for microbiological contamination and the measures to be taken. According to [32], most syrup contains the following components in addition to the purified water and any medicinal agents present. They are sweetening agents, antimicrobial preservatives, viscosity modifier, flavourings and colorants. Syrups as a pharmaceutical product requires safe, secure and tamper proof handling while packaging. The general process of packaging include; filling, sealing, capping, coding and labelling, wrapping. Cough syrups are not recommended in Canada and the United States for children 6 years or younger because of lack of evidence showing effect and concerns of harm [33]. Cough syrups are not recommended in Canada and the United States for children 6 years or younger because of lack of evidence showing effect and concerns of harm [34]. Syrups are appropriate for any patients, whatever the age is, they are the most natural and easiest route of administration, economical and safe to the patient and there is no nursing required, which means the patient can take it with no help whatsoever. In as much as there are several advantages of using syrups, the disadvantages are also not far-fetched and they include; Delayed onset of action because absorption takes time, not suitable in emergency and for unconscious patients, not convenient for a patient with a gastrointestinal disorder such as diarrhea, constipation, ulceration, and hyperacidity in stomach and it can't avoid first pass metabolism. Various syrups such as paracetamol, multivitamins and some blood syrups have become common habitat for microorganisms. In order to completely eliminate contamination by microorganisms, their mode of entry, characteristics and control must be studied. This research is designed to determine the bacteria present in syrups only and also prescribe measures that would be followed to prevent their transmission.

\section{Material and methods}

\subsection{Study area and population}

This study was carried out in the Department of Microbiology, Federal University Wukari, Taraba State, Nigeria. Wukari metropolis is a large town which is the Headquarter of Wukari Local Government Area of Taraba State. Geographically, Wukari lies between latitude $7^{\circ} 55^{\prime} 42^{\prime \prime}$ North and longitude $9^{\circ} 47^{\prime} 59^{\prime \prime}$ East. It has an area of 4,308 km2. Wukari is home to Federal University Wukari, National Open University of Nigeria study center and Kwararafa University. It is an important town in Taraba state, characterized with agricultural activities among other activities. The average annual temperature in Wukari is $26.8^{\circ} \mathrm{C}$, with March being the hottest month with an average temperature of $29.8^{\circ} \mathrm{C}$ and August has the lowest average temperature with $25.4^{\circ} \mathrm{C}$. The average precipitation is $1205 \mathrm{~mm}$. The major languages spoken are Jukun, Kutep, Tiv, Hausa and Fulani [22].

\subsection{Sample Collection and Cultural analysis}

Commercially marketed syrup samples were purchased from 3 different pharmacies located in different area of Wukari in their already sealed and labelled bottles and was transported to the Department of Microbiology laboratory without delay for culture using standard microbiological methods. Ten (10) syrups from New World Patent Medicine Store, six (6) from Sir Joe Patent Medicine Store and two (2) from El-samina Pharmacy were included in the study. These syrups were the cough syrups, prophylactic syrups, digestion syrups, vitamin syrups, multivitamin syrups, blood tonic and antimalarial syrups, all from Emzor, Jawa, Tuyil pharmacy and M\& B brands.

\subsection{Identification of isolates}

Pour plate method was used for culturing samples. The culture media used were MacConkey agar, Nutrient agar and CLED agar prepared according to the manufacturer's instructions. One millilitre (1ml) of each sample was withdrawn aseptically using sterile syringe into corresponding labelled tube. The screw caps of the tubes were tightly covered and agitated properly to ensure the complete dissolution and homogenization of the drug sample. One millilitre ( $1 \mathrm{ml}$ ) from each bottle was transferred aseptically into an empty petri dish before adding molten agar to it. The plate was swirled gently to mix before allowing it to set. Cultured plates where then incubated at ambient temperature of $37^{\circ} \mathrm{C}$ for 24 hours. Distinct colonies from the 24 hours culture was isolated and sub cultured on freshly prepared media plates using streak plate methods. Standard microbiological techniques were then used for final identification procedures of isolates. 


\section{Results}

Three (3) pharmacies and patent medicine stores were visited in Wukari and syrups samples were collected and analysed for bacteria contaminants.

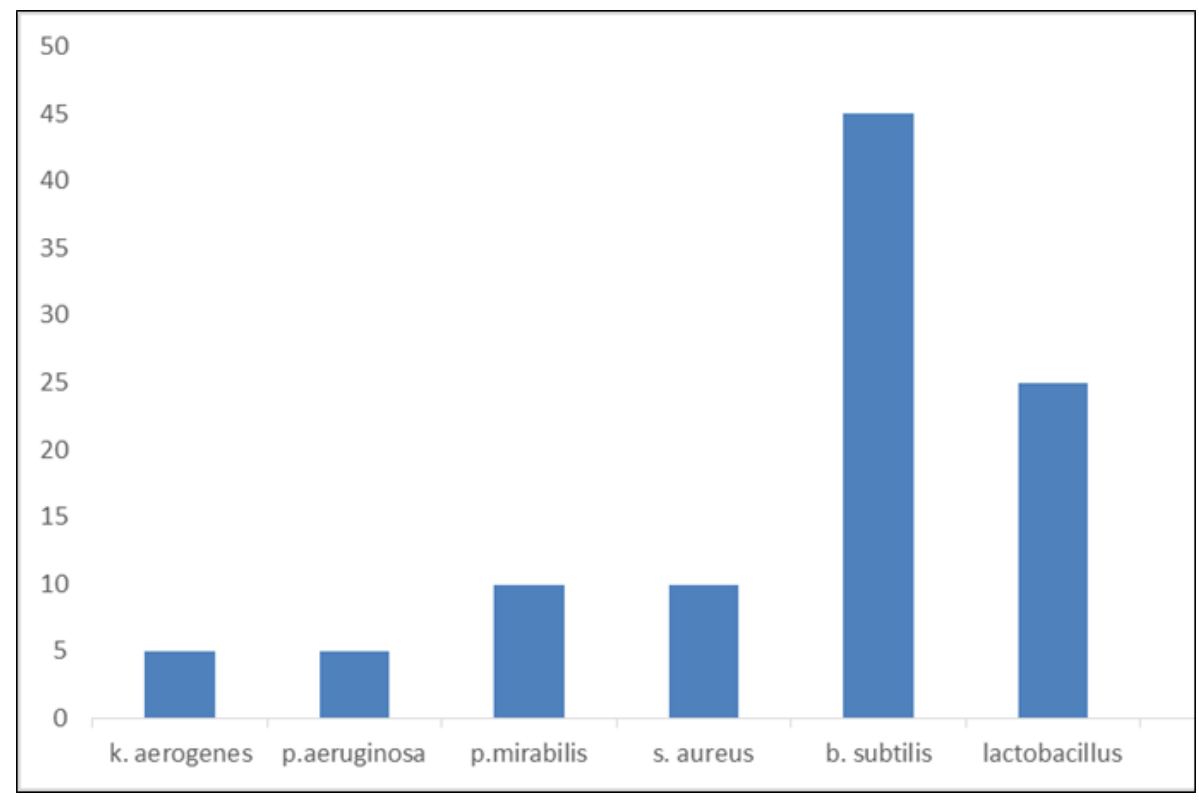

Figure 1 Distribution of isolates in various samples

Table 1 Bacterial Contamination Per Sample Analysed

\begin{tabular}{|c|c|c|c|c|c|c|}
\hline Samples & Bacillus & Lactobacillus & Proteus & Pseudomonas & Klebsiella & S.aureus \\
\hline A1 & + & + & - & - & - & - \\
\hline $\mathrm{A} 2$ & + & + & - & - & - & - \\
\hline $\mathrm{B} 1$ & $\mathrm{NG}$ & $\mathrm{NG}$ & NG & NG & $\mathrm{NG}$ & $\mathrm{NG}$ \\
\hline B2 & - & - & - & - & - & + \\
\hline $\mathrm{C} 1$ & $\mathrm{NG}$ & $\mathrm{NG}$ & $\mathrm{NG}$ & NG & NG & NG \\
\hline $\mathrm{C} 2$ & - & + & - & - & - & + \\
\hline D1 & $\mathrm{NG}$ & $\mathrm{NG}$ & NG & NG & $\mathrm{NG}$ & $\mathrm{NG}$ \\
\hline D2 & - & - & - & + & + & - \\
\hline E1 & + & - & - & - & - & - \\
\hline E2 & $\mathrm{NG}$ & NG & $\mathrm{NG}$ & NG & NG & $\mathrm{NG}$ \\
\hline $\mathrm{F} 1$ & $\mathrm{NG}$ & NG & NG & NG & NG & $\mathrm{NG}$ \\
\hline $\mathrm{F} 2$ & $\mathrm{NG}$ & $\mathrm{NG}$ & $\mathrm{NG}$ & $\mathrm{NG}$ & $\mathrm{NG}$ & $\mathrm{NG}$ \\
\hline G1 & + & - & - & - & - & - \\
\hline $\mathrm{G} 2$ & - & + & - & - & - & - \\
\hline $\mathrm{H} 1$ & - & - & + & - & - & - \\
\hline $\mathrm{H} 2$ & + & - & - & - & - & - \\
\hline $\mathrm{I} 1$ & + & - & + & - & - & - \\
\hline $\mathrm{I} 2$ & + & - & - & - & - & - \\
\hline
\end{tabular}


Table 2 Morphological and biochemical characteristics of various isolates

\begin{tabular}{|c|c|c|c|c|c|c|c|c|c|c|c|c|}
\hline sample & $\begin{array}{l}\text { Cultural } \\
\text { characteristic }\end{array}$ & $\begin{array}{l}\text { Gram's } \\
\text { reaction }\end{array}$ & Catalase & Coagulase & Indole & M.red & Lactose & Sucrose & Glucose & Fructose & Galactose & Isolates \\
\hline 1 & $\begin{array}{l}\text { Pink round } \\
\text { colony }\end{array}$ & - & + & - & - & - & + & + & + & + & + & Klebsiella spp \\
\hline 2 & $\begin{array}{l}\text { Pink round } \\
\text { colony }\end{array}$ & - & + & - & - & - & - & + & - & - & - & Pseudomonas spp \\
\hline 3 & $\begin{array}{l}\text { White } \\
\text { spreading } \\
\text { colony }\end{array}$ & - & + & - & - & + & - & - & + & + & + & Proteus spp \\
\hline 4 & $\begin{array}{l}\text { White } \\
\text { spreading } \\
\text { colony }\end{array}$ & + & + & + & - & + & + & + & + & + & + & Staphylococcus aureus \\
\hline 5 & $\begin{array}{l}\text { Round creamy } \\
\text { colony }\end{array}$ & + & + & - & - & - & + & + & + & + & + & Lactobacillus spp \\
\hline 6 & $\begin{array}{l}\text { White mould } \\
\text { colony }\end{array}$ & + & + & + & - & - & + & + & + & + & + & Bacillus spp \\
\hline
\end{tabular}


The syrups samples with contaminants included the M \& B paracetamol, Emzor paracetamol, M \& B flagyl (Loxagyl), Emzor Chloroquin, M \& B Antimalarial preparation (Artelumex), Emzor cough syrup (Emzolyn), Emzor digestion syrup (Emtrisil), Jawa digestion syrup (Jawasil), Emzor multivitamin (Emvite), Tuyil pharmacy multivitamin (Vami-vite), Emzor blood tonic, and Jawa blood tonic while those that contained no contaminants included the Emzor flagyl(Emgyl), M \& B chloroquin(Vinaquin), Emzor antimalarial preparation (Lokmal), Jawa cough syrup(D-Koff), Emzor vitamin c and Tuyil pharmacy vitamin C. Tables'1, 2 and 3 below showed individual sample isolates, the cultural and biochemical characteristics of various isolates and also their percentage of occurrence. The identification of microbial contaminants such as staphylococcus aureus, proteus spp, pseudomonas spp and klebsiella spp showed that there are microbiological contaminants of pharmaceutical syrups. Figure 1 and 2 below describes the distribution of the isolates found in the samples that were examined. It was shown that Bacillus spp and the Lactobacillus spp were the predominant organisms in the syrups examined even though staphylococcus aureus, proteus spp, pseudomonas spp and klebsiella spp were also isolated.

Table 3 Frequency of occurrence of various isolates

\begin{tabular}{|l|c|c|c|}
\hline Isolates & Frequency & Percentage\% & Degree \\
\hline Klebsiella spp & 1 & 5 & 18 \\
\hline Pseudomonas spp & 1 & 5 & 18 \\
\hline Proteus spp & 2 & 10 & 36 \\
\hline Staphylococcus aureus & 2 & 10 & 36 \\
\hline Bacillus spp & 9 & 45 & 162 \\
\hline Lactobacillus spp & 5 & 25 & 90 \\
\hline Total & 20 & 100 & 360 \\
\hline
\end{tabular}

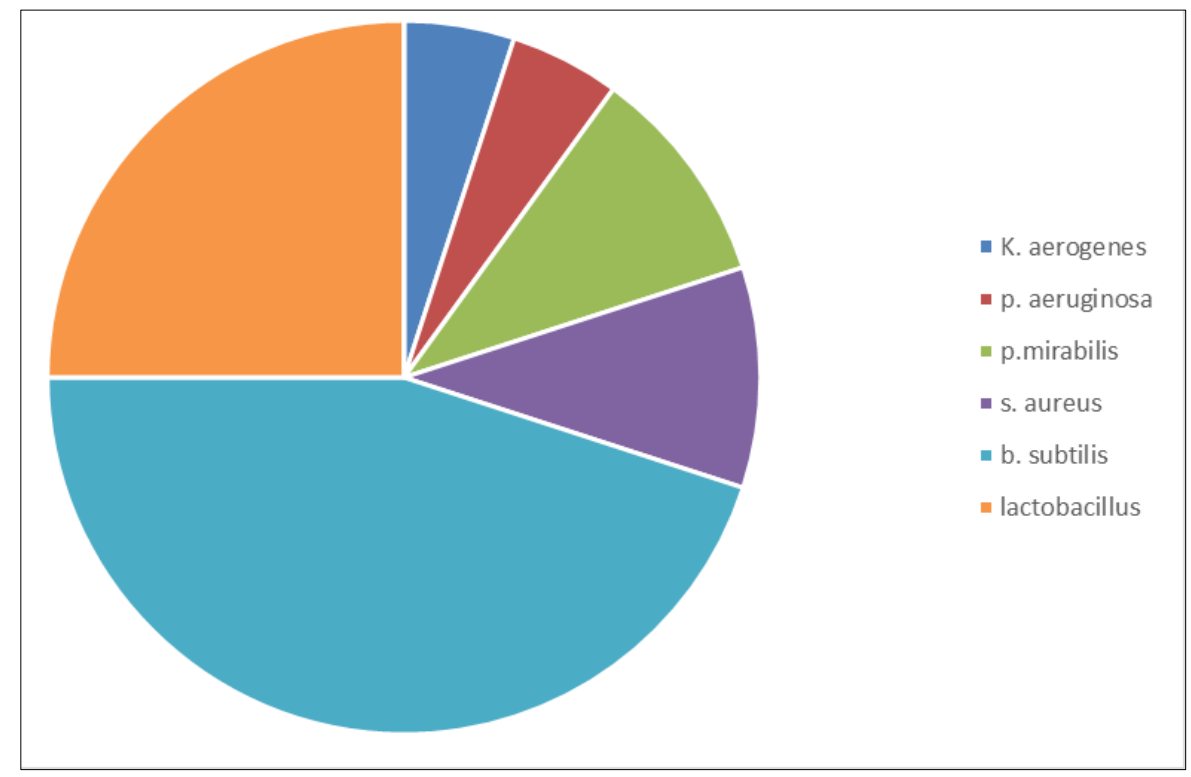

Figure 2 Distribution of bacterial isolates using a Pie Chart

\section{Discussion}

Microbiological contamination of retailed drugs (syrups) were investigated and the presence of microbial contamination showed that syrups though used to treat sick infants and illness can also be contaminated with microorganisms, indicating a defect in production and packaging. The results of this researched showed that the various syrup sold in selected patent medicine store in various neighbourhood in Wukari was contaminated with bacteria. This study revealed that bacillus spp was the most predominant bacteria in syrups which aligned with that reported in Ewohimi by [22]. Other organisms like the pseudomonas, proteus, staphylococcus aureus and klebsiella species were also 
isolated from the syrup samples and were also aligned with the study done by [33] in Ewohimi. These bacterial species have also been previously associated with drug contaminations $[9 ; 10]$.

Only six brands out of the eighteen brands of syrups examined had no bacterial contamination which implies that the drugs complied with the official requirement for the microbiological quality of syrups and suspensions according to the [9]. The percentage of contamination ranged from $5 \%$ to $45 \%$ which also aligned with the work of [10] and also the types of bacterial contaminants isolated suggest the route of contaminations to be possibly water, personnel and environment. It can also be attributed to poor manufacturing practice; the raw materials, the air in the manufacturing environment, water used or the personnel involved, packaging process or containers and equipment [7]. The results obtained in this study also showed that $45 \%$ of the tested samples were contaminated with Bacillus spp which tallies with the work of [10] showing that Bacillus was the most frequent contaminant of non-sterile pharmaceutical products. Members of this genus are widespread in the air, soil, water and in animal products such as hair, wool and carcasses [34]. As it has been reported by [35] that most liquid drugs were commonly contaminated by Pseudomonas aeruginosa, which is a recalcitrant drug contaminant and Staphylococcus aureus were isolated from these syrups too. The Pseudomonas contamination of this sample is of great public health significance, as Pseudomonas aeruginosa isolated from environment often present resistance to clinically available of antimicrobial agents. Furthermore, in accordance with the Reports of Mixed Working Committee of Official Laboratory and Drug Control Services and a section of the International Pharmaceutical Federation, liquid pharmaceutical preparations are to be devoid of Escherichia coli and other coliforms such as Pseudomonas aeruginosa, Staphylococcus aureus and as well as other pathogens. Therefore, presence of any microorganism should be considered undesirable for all drugs.

\section{Conclusion}

Although specific Gram negative enteric bacteria were not found in the tested samples, presence of viable bacteria especially Gram positive ones claimed a sort of public health risk associated with the consumption of those drugs in this study, The result shows that of the eighteen (18) different syrups, twelve (12) were contaminated with bacterial isolates. Based on the result of this research work, there is a need for proper monitoring and quality control among producers, health workers, and drug vendors to ensure that correct guidelines for these syrups are maintained. The government agencies such as Nigerian Drug Law Enforcement Agency (NDLEA) and National Agency for Food and Drug Administration and Control (NAFDAC) should subject the pharmaceutical industries and their products to routine monitoring and supervision to ensure strict compliance to good manufacturing practice. Proper attention should be given to the prior treatment of these syrups to ensure reduction in the level of microbial contaminants. The incorporation of sufficient concentration of appropriate preservatives can also be employed to reduce the microbial load of these preparations. It is therefore recommended that monitoring agencies should ensure that these drugs do not present health hazards to the public during production and final consumption by end users.

\section{Compliance with ethical standards}

\section{Acknowledgments}

We thank the staff of Federal University Wukari, Taraba State, Nigeria for the use of their Laboratory Equipment for various Analyses.

\section{Disclosure of conflict of interest}

No conflict of interest reported, Authors unanimously agree with the publication of this scientific work.

\section{References}

[1] Saunders Comprehensive Veterinary Dictionary. 3 ed. Elsevier, Inc. All rights reserved. 2017.

[2] Aulton ME. Pharmaceutics: The science of dosage form design. (2nd ed). London, UK: Churchill Livingstone. 2002.

[3] Mwambete KD, Justin-Temu M, Fazleabbas SF. Microbiological assessment of commercially available quinine syrups and water for injections in Dares Salaam, Tanzania. Tropical Journal for Pharmaceutical Resources. 2009; 8(5): 441-447.

[4] World Health Organization. International Pharmacopoeia. (WHO). 4th ed. Switzerland. 2018. 
[5] Nester MT, Anderson DG, Robert CE, Peasail NN. Microbiology- A human perspective genitourinary infections and antimicrobial medications (3rd ed.). 2012.

[6] Parker MS. Microbiological Contamination and Preservation of Pharmaceutical Preparations. In; Aulton, ME; editor. Pharmaceutics; The Science of Dosage from Design, Hong Kong, china; Churchill livingstone. 2010.

[7] Baird R, Stephen P, Denyer Norman A, Hodges Sean P, Gorman. Microbial spoilage, infection risk and contamination control. In: Pharmaceutical Microbiology. 7th ed. Blackw++2xell publishing company, Massachusetts U.S.A. 2014; 263-284.

[8] Mugoyela V, Mwambete KD. Microbial contamination of nonsterile pharmaceuticals in public hospital settings. Therapeutics and Clinical Risk Management. 2010; 6: 443-448.

[9] Takon AI, Antai SP. Microbial contamination of expired and unexpired aqueous and suspension drugs sold in some patent medicine stores in Calabar. Nigeria Journal of Microbiology. 20(2): 1096-1103.

[10] Ibezim EC, Esimme CO, Ofeofule SJ, Chah KF. Journal phytomedical therapy. 2012; 7(1 \& 2): 18-25.

[11] Moniruzzaman M, Ashrafi MFF, Mia Z. Qualitative and quantitative microbiological studies of antacid and paracetamol suspensions from different drug stores of Dakar. Dhaka university journal biological science. 2012; 21(1): 105-107.

[12] Smith SM, Schroeder K, Fahey T. Over the counter medications for acute cough in children and adults in community settings. The Cochrane database of systematic reviews. 2014; 11: CD001831.

[13] Ahsanul Haque Chowdhury Pulok. Dakhar Bangladesh. 2014.

[14] Mendie UE, Hugbo PG. The antibacterial potential of some intravenous fluid additives. Journal for West African Pharmacy. 2013; 7: 18-21.

[15] Kramer A, schwebke I, kampf G. How long do nosocomial pathogens persist on inanimate surfaces? A systematic review. BMC infectious disease. 2016; 6(1).

[16] Nirmala MJ, Chandrasekaran N, Mukherjee A. Enhanced solubilization of aqueous insoluble anti-hypertension drug. International Journal for Pharmaceutical Science. 2012; 4(5): 366-368.

[17] Hugbo PG, Onyekweli AO, Igwe I. Microbial contamination and preservative capacity of some brands of cosmetic creams. Tropical journal of pharmaceutical research. 2018; 2(2): 229-234.

[18] Goldberg RA, Flynn HW, JR, Isom RF, Miller D, Gonzalez S. An outbreak of streptococcus endophthalmitis after intravitreal injection of bevacizumab. American Journal of Ophthalmology.2012; 153: 204-208.

[19] Imarenezor E.P.K., Ebuara F.U., Abhadionmhen O. A., Brown S.T.C., Apine D and Isaac K. (2020). Antibacterial activity of some selected medicated soap on staphylococcus aureus from wound infections. Global Scientific Journals 8(9):1196 - 1205. EOI:10.11216/gsj.2020.09.44268

[20] Kenneth Todar. The Normal Bacterial Flora of Humans. Todar's online text book of bacteriology. 2012.

[21] Patricia V. Staphylococcus aureus Sepsis and the Waterhouse-Friderichsen Syndrome in Children. Nigerian English Journal Medicine. 2015; 353: 1245-1251 7.

[22] Imarenezor EPK, Brown STC, Yakubu OE, Soken DC. Survey of Hepatitis B and C among students of Federal University Wukari, Taraba State, Nigeria. International Research Journal of Medicine and Medical Sciences. 2016; 4(3): 31-37.

[23] Al-Charrakh AH. Frequency and antimicrobial resistance of bacteria isolated from oral and topical medicaments from Hilla, Iraq. Journal for Infections in Developing Countries. 2018; 6: 489-94.

[24] Christian G. Clinical and Economic Impact of Common Multidrug-Resistant Gram-Negative Bacilli. Antimicrobial. Agents chemotherapy. 2018; 52: 813-821.

[25] Richard, Warrington and Fanny Silviu-Dan. Drug allergy. Allergy Asthma Clinical Immunology. 2011.

[26] Sheikh J. Intrapartum anaphylaxis to penicillin in a woman with rheumatoid arthritis who had no prior penicillin allergy.Annals of Allergy, Asthma and Immunology. 2007; 99: 287-9.

[27] Munoz JM, Zapien R, Ponce-De-Leon S, Alvarez JA, Mosqueda JL, Gallaga JC, Macias AE. Endemic intravenous fluid contamination in pediatric wards. Revised Investment Clinic. 2019; 61: 378-82. 
[28] Qin X, Guo S. Mould and Mycotoxin Contamination of Medicinal Material. ZhongguoZhong Yao ZaZhi: China Journal of material medication. 2017; 36: 33-44.

[29] Hayden MK, Blom DW, Kyle EA, Moore CG, Weinstein RA. Risk of hand or glove contamination after contact with patients colonized with vancomycin- resistant enterococcus or the colonized patients environment. Infection control. 2018; 29(02): 149-154.

[30] Hossain J. Importance of the bioburden test in pharmaceutical quality control. Pharmaceutical Microbiology Forum. 2019; 15(1): 2-14. 5.

[31] Fazio TT, Singh AK, Kedor-Hackmann ER, Santoro MI. Quantitative determination and sampling of azathioprine residues for cleaning validation in production area. Journal of Pharmaceutical and Biomedical Analysis. 2017; 43: 1495-8.

[32] Shefrin and Goldman, Goldman RD. Use of over the counter cough and cold medications in children. Canadian family physician. 2019; 55(11): 1081-1083.

[33] Imarenezor EPK. Microbiological quality of some commercially available anti-malarial syrup in Ewohimi, Nigeria. Nigeria Journal of Science. 2019; 10: 10-17.

[34] Willey JM, Sherwood LM, Woolverton CJ. Prescott, Harley and Klein's Microbiology. 7th ed. McGrawHill Company, New York, America. 2018; 578.

[35] Imarenezor E.P.K., Ebuara F.U., Abhadionmhen O. A., Brown S.T.C., and Isaac K. (2020). Antimicrobial effects of chromolaena odorata leaves on Staphylococcus aureus and Streptococcus spp isolates from Wound in Wukari, North East, Nigeria. Global Scientific Journals 8(9):1183 - 1195. EOI: 10.11216/gsj.2020.09.43698 